\title{
Ethanol content determination in hard liquor drinks, beers, and wines, using a catalytic fuel cell. Comparison with other two conventional enzymatic biosensors: correlation and statistical data
}

\author{
M. Tomassetti, R. Angeloni, M. Castrucci, E. Martini, L. Campanella \\ Department of Chemistry, University of Rome "La Sapienza", Rome, Italy
}

\section{ABSTRACT}

A catalytic fuel cell has been employed to check ethanol content in several samples of commercial wines, beers and hard liquor drinks. Two other conventional biosensors, based on catalase or alcohol oxidase enzyme, were also used to the same purpose on the same samples. Data obtained by the three sensor methods have been compared and correlated. Lastly t-test and F-test were applied.

\section{Section: RESEARCH PAPER}

Keywords: analysis by catalytic fuel cell; ethanol in beverages and hard liquors; statistical data; correlation with other biosensors

Citation: M. Tomassetti, R. Angeloni, M. Castrucci, E. Martini, L. Campanella, Ethanol content determination in hard liquor drinks, beers, and wines, using a catalytic fuel cell. Comparison with other two conventional enzymatic biosensors: correlation and statistical data, Acta IMEKO, vol. 7, no. 2, article 16, June 2018, identifier: IMEKO-ACTA-07 (2018)-02-16

Section Editor: Claudia Zoani, Italian National Agency for New Technologies, Energy and Sustainable Economic Development affiliation, Rome, Italy Received February 1, 2017; In final form May 21, 2018; Published June 2018

Copyright: @ 2018 IMEKO. This is an open-access article distributed under the terms of the Creative Commons Attribution 3.0 License, which permits unrestricted use, distribution, and reproduction in any medium, provided the original author and source are credited

Funding: This work was funded by University of Rome "La Sapienza", Center "Protezione dell'Ambiente e dei Beni Culturali (CIABC)" and "Istituto per lo Studio dei Materiali Nanostrutturati (ISMN)" of CNR

Corresponding author: Mauro Tomassetti, e-mail: mauro.tomassetti@uniroma1.it

\section{INTRODUCTION}

Our team recently investigated the feasibility of using an adapted small catalytic 'fuel cell' (see Figure 1), originally constructed for the purpose of obtaining energy from methanol or ethanol, for analytical purposes [1], [2], based on the following reaction: $\mathrm{C}_{2} \mathrm{H}_{5} \mathrm{OH}+3 \mathrm{H}_{2} \mathrm{O} \longrightarrow 12 \mathrm{H}^{+}+12 \mathrm{e}^{-}+$ $2 \mathrm{CO}_{2}$. The goal was to see whether this kind of device can also be used for ethanol determination in real samples. Actually, there is no lack of analytical methods for the determination of ethanol in alcoholic beverages, such as chromatographic [3]-[5], colorimetric [6], [7], NIR [8], [9], IR [10] and titrimetric [11] methods. However, the possibility of using Direct Methanol (or ethanol) Catalytic Fuel Cell (DMFC) for analytical purposes has not been sufficiently investigated, so this aspect has been studied by our research group in recent times [1], [2].

\section{METHODS}

To this end water-alcohol solutions containing increasing percentages of ethanol were added to the cell, recording the current increase that occurs between two electrodes of the cell,

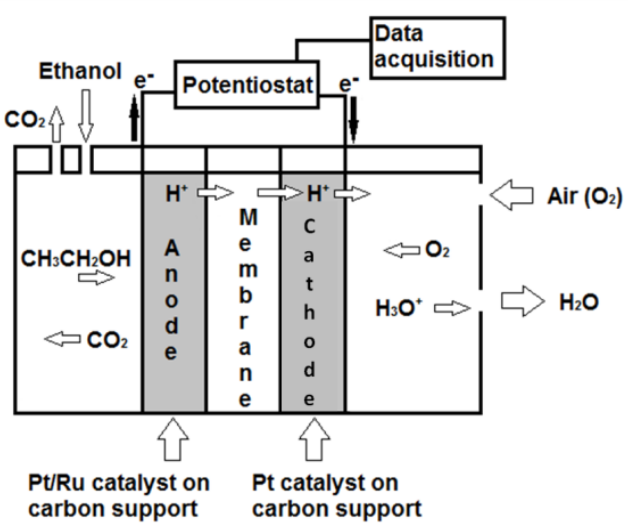

Figure 1. DMFC device functioning layout. 
working under potentiostatic control. Lastly, once the current achieved the steady state, after each hydroalcoholic addition, calibration curves for ethanol were obtained.

Owing to the good analytical results obtained operating on standard ethanol solutions, the fuel cell was then used to check the ethanol content in several wine, beer and hard liquor commercial drink samples.

Results obtained analyzing red and white wines or beers are also compared with those obtained using two conventional different enzyme electrodes that have been fabricated by immobilizing either alcohol oxidase, or catalase, in kappaCarrageenan gel layer overlapped to an amperometric gaseous diffusion Clark type oxygen electrode. The variation of the oxygen concentration in the aqueous solution, due to the enzymatic reactions, was measured at a constant applied potential of $-650 \mathrm{mV}$. In the case of the catalase electrode [12], [13], the measurement was performed by adding hydrogen peroxide to a buffer solution which was diffused through the dialysis membrane towards the enzymatic layer where the reaction catalysed by the catalase enzyme took place:

$\mathrm{H}_{2} \mathrm{O}_{2} \stackrel{\text { Catalase }}{\longrightarrow} 1 / 2 \mathrm{O}_{2}+\mathrm{H}_{2} \mathrm{O}$. Since this reaction led to the production of oxygen, the concentration of the latter in the measurement solution increased. This increase triggered an increase in the cathodic current, which increased from the original value to a new value corresponding to a new stationary state. At this stage, further additions (equal to $20 \mu \mathrm{L}$ ) of a standard solution of ethanol were made; after each addition a catalyzed reaction of the following type occurred:

$\mathrm{CH}_{3} \mathrm{CH}_{2} \mathrm{OH}+\mathrm{H}_{2} \mathrm{O}_{2} \stackrel{\text { Catalase }}{\longrightarrow} \mathrm{CH}_{3} \mathrm{CHO}+2 \mathrm{H}_{2} \mathrm{O}$. The second reaction removed part of the $\mathrm{H}_{2} \mathrm{O}_{2}$ substrate from the first reaction, which was slowed down; this slowdown was accompanied by a decrease in the level of oxygen produced in the solution during the first reaction; that was evidenced by the decrease in the measured cathodic current which attained a new stationary state after each addition of alcohol solution. The current variation was read off after each alcohol addition [12], [13]. When the biosensor used alcohol oxidase, the operating procedure was much simpler [12] as it consisted of directly making successive additions of the standard ethanol solution to a buffer solution in which the measurement was being performed. After each addition a reaction catalyzed by the alcohol oxidase enzyme of the following type took place:

$\mathrm{CH}_{3} \mathrm{CH}_{2} \mathrm{OH}+\mathrm{O}_{2} \stackrel{\text { Alcohol oxidase }}{\longrightarrow} \mathrm{CH}_{3} \mathrm{CHO}+\mathrm{H}_{2} \mathrm{O}_{2}$. The reaction led to the oxygen present in the solution being consumed with a consequent decrease in the cathodic current, which was measured until a new stationary state was reached. Also, in this case, the current variation was read off after each addition. All the experiments were carried out in a reaction cell thermostated at $23^{\circ} \mathrm{C}$ containing $15 \mathrm{~mL}$ of $0.05 \mathrm{~mol} \mathrm{~L}^{-1}$ phosphate buffer solution.

\section{RESULTS}

The effect of $\mathrm{pH}$ on the response of the conventional biosensors, investigated in detail, showed that the best $\mathrm{pH}$ was 7.5 for the catalase electrode and 8.0 for the alcohol oxidase electrode, respectively. The catalase biosensor displayed a much greater sensitivity to ethanol than, for instance, methanol, unlike the alcohol oxidase biosensor. The catalase biosensor also displayed a stability and a life-time higher than that of the alcohol oxidase biosensor, as well as a Limit of Detection (LOD) at least one decade lower. It also displayed a better repeatability and reproducibility for ethanol standard solutions. On the other hand, the alcohol oxidase biosensor was found to be more sensitive to methanol than to ethanol, but allowed the test to be carried out slightly faster than with the catalase device. The method based on the catalytic fuel cell is very simple, inexpensive, and its lifetime is also very long, in practice longer than three months. The only drawback of the catalytic fuel cell was its long response time, but its lifetime was very long if compared to those of the two conventional enzyme electrodes.

A comparison of the main analytical results [1] for the three used devices is done in the Table 1 , for the convenience of the reader.

A comparison between the results obtained applying the catalytic fuel cell and two conventional amperometric enzymatic sensors was also performed by studying the correlation of results obtained by applying the three methods for ethanol content determination in several commercial wines and beers (see Figures 2-4).

Table 1. Table1. Main analytical results.

\begin{tabular}{|l|l|l|l|l|}
\hline \multicolumn{1}{|c|}{ Method } & $\begin{array}{c}\text { Linearity } \\
\text { range(M) }\end{array}$ & LOD(M) & $\begin{array}{c}\text { Life time } \\
\text { (days) }\end{array}$ & $\begin{array}{c}\text { Analysis } \\
\text { time } \\
\text { (min) }\end{array}$ \\
\hline $\begin{array}{l}\text { Catalase } \\
\text { biosensor }\end{array}$ & $\begin{array}{l}2.0 \times 10^{-6}- \\
2.0 \times 10^{-5}\end{array}$ & $0.4 \times 10^{-6}$ & $\approx 30$ & $\approx 34$ \\
\hline $\begin{array}{l}\text { Alcohol oxidase } \\
\text { biosensor }\end{array}$ & $\begin{array}{l}9.2 \times 10^{-6}- \\
3.4 \times 10^{-4}\end{array}$ & $3.6 \times 10^{-6}$ & $\approx 7$ & $\approx 25$ \\
\hline $\begin{array}{l}\text { Fuel Cell (SC) } \\
\text { potentiostatic } \\
\text { format at OAP }\end{array}$ & $\begin{array}{l}1.0 \times 10^{-3}- \\
4.0 \times 10^{-2}\end{array}$ & $8.0 \times 10^{-4}$ & $>90$ & $\approx 55$ \\
\hline
\end{tabular}

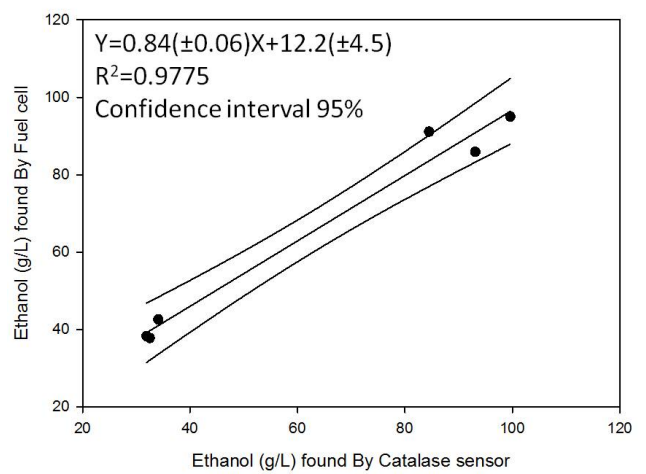

Figure 2. Correlation between results found by Fuel cell and Catalase biosensor.

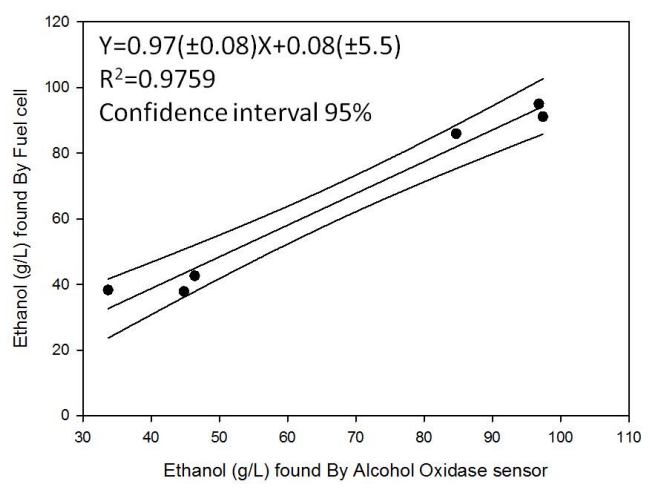

Figure 3. Correlation between results found by Fuel cell and Alcohol oxidase biosensor. 


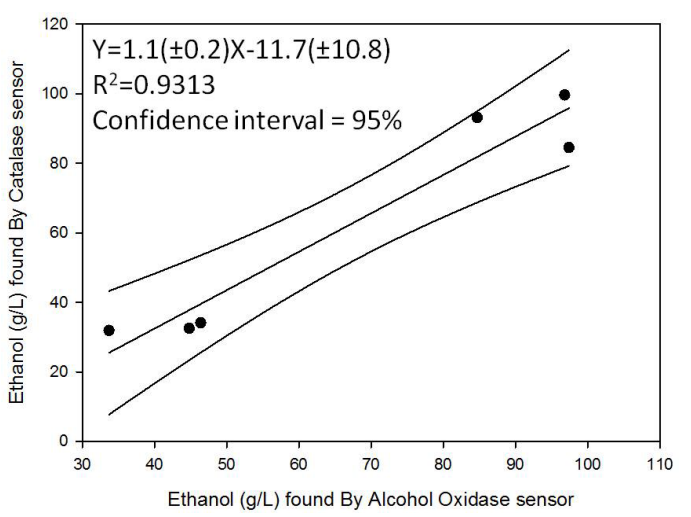

Figure 4. Correlation between results found by Catalase biosensor and Alcohol oxidase biosensor.

It can be observed that the alcoholic content of the beer samples is about three times lower than that of wine samples. However, the correlations found between fuel sensor data and the data obtained using the two biosensor methods are sufficiently good and better than those observed between the two enzyme biosensor methods. In addition, the correlation of data from each method and the nominal values given by beverages producer firms (Figures 5, 6 and 7) was also evaluated and found satisfactory.

Also in this case the best correlation was found when the fuel cell was used. Lastly, also t-test was applied (Table 2).

Moreover, a statistical evaluation of variance by F-test was performed. See Table 3.

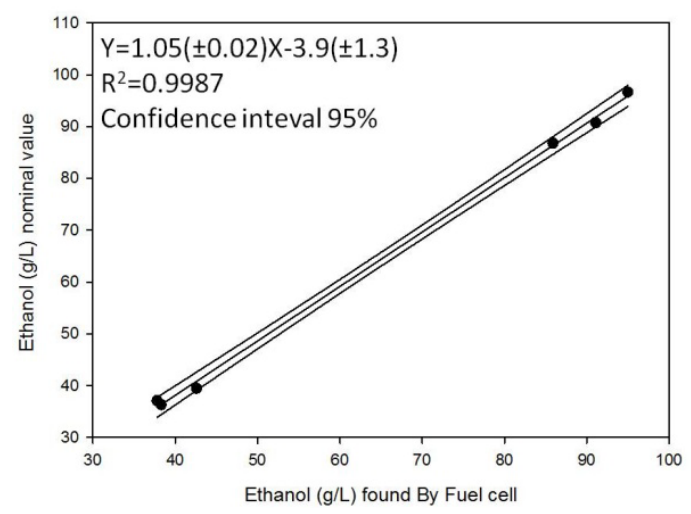

Figure 5. Correlation between nominal values and results found by Fuel cell.

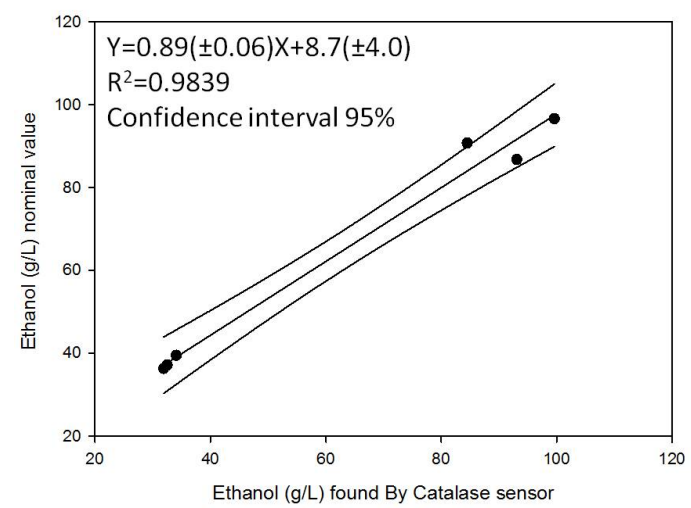

Figure 6. Correlation between nominal values and results found by Catalase biosensor.

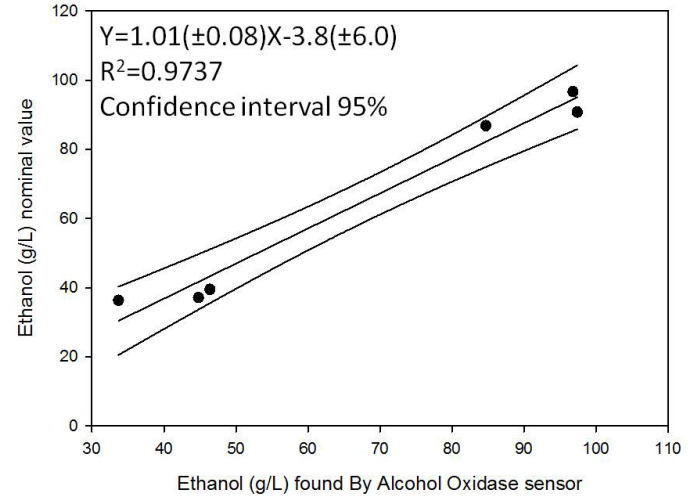

Figure 7. Correlation between nominal values and results found by Alcohol oxidase biosensor.

Table 2. Paired t-test, two sided, $v=5,(p=95 \%)$ applied to values obtained by three methods for beers and wines samples vs nominal values.

\begin{tabular}{|c|c|c|}
\hline $\begin{array}{c}\text { By Catalase } \\
\text { biosensor }\end{array}$ & $\begin{array}{c}\text { By Alcohol } \\
\text { oxidase } \\
\text { biosensor }\end{array}$ & By Fuel cell \\
\hline \multicolumn{3}{|c|}{ t-experimental } \\
\hline-0.8881 & 1.421 & 0.8476 \\
\hline \multicolumn{3}{|c|}{ t-critical } \\
\hline 2.571 & 2.571 & 2.571 \\
\hline $\mid$ t-exp. $\mid<\mathrm{t}$-cr. & t-exp. $\mid<\mathrm{t}$-cr. & $\mid$ t-exp. $\mid<\mathrm{t}$-cr. \\
\hline \multicolumn{3}{|c|}{ Results of t-test } \\
\hline Not significant & Not significant & Not significant \\
\hline
\end{tabular}

Table3. F-test: comparison among precisions, two sided ( $p=95 \%)$.

\begin{tabular}{|c|c|c|c|}
\hline Samples & \multicolumn{3}{|c|}{ Result of the F-test } \\
\hline $\begin{array}{c}\text { Alcohol oxidase } \\
\text { vs. Catalase } \\
\text { biosensor }\end{array}$ & $\begin{array}{c}\text { Fuel cell vs. } \\
\text { Catalase } \\
\text { biosensor }\end{array}$ & $\begin{array}{c}\text { Fuel cell vs. } \\
\text { Alcohol } \\
\text { oxidase } \\
\text { biosensor }\end{array}$ \\
\hline B.n.1 & N.S. & S. & S. \\
\hline B.n.2 & N.S. & N.S. & N.S. \\
\hline B.n.3 & N.S. & S. & S. \\
\hline W.n.1 & N.S. & N.S. & N.S. \\
\hline W.n.2 & N.S. & N.S. & N.S. \\
\hline W.n.3 & N.S. & N.S. & N.S. \\
\hline W.n.4 & N.S. & N.S. & N.S. \\
\hline
\end{tabular}

N.S.= Not Significant; S.= Significant; B.= beer; W.= wine

As reported in Figure 8, the comparison between the results

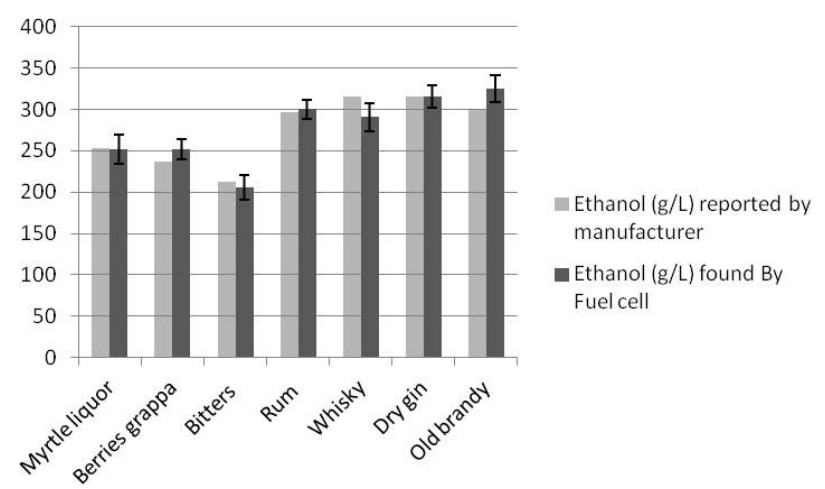

Figure 8. Agreement between nominal values and results found by Fuel cell for the hard liquor drinks. 
concerning the ethanol content, determined in several hard liquor drinks using the catalytic fuel cell, and the nominal values given by producers exhibits a good agreement.

Lastly, in Table 4 all the found results concerning the ethanol content in hard liquor drinks and the applied t-test are displayed.

\section{CONCLUSIONS}

As previously mentioned in the introduction, there is no lack of classic analytical methods, including biosensoristic methods (see for instance Ref. [14]), for ethanol determination in alcoholic beverages. However, the main objective of this research was to test a method based on a DMFC device, used so far especially for energy production purposes and to propose this alternative device also for analytical purposes. The advantages can be identified above all in the extremely low cost of this fuel cell based sensor, with respect to both other analytical instrumental methods [3]-[10] and conventional enzymatic biosensors for ethanol [10]-[16]. In comparison with conventional biosensors, it is sufficient to pay attention to the long lifetime of our proposed device, which does not require special precautions to be used for long periods. For completeness of the research, the main performances of this device were analytically compared with those of two conventional enzyme biosensors, even if based on different enzymatic reactions. As previously mentioned, this kind of biosensors is already extensively reported in the literature [14][16]. So those two, developed and used by us (based for instance on a different type of enzyme, but on the same enzyme immobilization method) and well tested in our previous works (see Ref. [12] and [13]), showed on "average" a performance not very different from other conventional enzymatic biosensors of the same type. The results demonstrated a good correlation between the three different methods as well as with the nominal values. The F-test evidenced that the repeatability of the three methods is usually of the same order. The analysis of the obtained data highlights that the catalytic fuel cell may be considered a suitable analytical device to check ethanol content in commercial beverages and hard liquor drinks at low cost and in a simple way. The comparison with two other conventional enzymatic biosensor methods confirms this assertion. It is also interesting, for instance, to observe that the best correlation between experimentally determined and nominal values (see $\mathrm{R}^{2}$ ) was found only in the case of the catalytic fuel cell device.

\section{ACKNOWLEDGEMENT}

This work was funded by University of Rome "La Sapienza", Center "Protezione dell'Ambiente e dei Beni Culturali (CIABC)" and "Istituto per lo Studio dei Materiali Nanostrutturati (ISMN)" of CNR.

\section{REFERENCES}

[1] M. Tomassetti, R. Angeloni, G. Merola, M. Castrucci, L. Campanella, Catalytic fuel cell used as an analytical tool for methanol and ethanol determination. Application to ethanol determination in alcoholic beverages, Electrochim. Acta 191 (2016) pp. 1001-1009.

[2] M. Tomassetti, G. Merola, R. Angeloni, S. Marchiandi, L. Campanella, Further development on DMFC device used for analytical purpose: real applications in the pharmaceutical field and possible in biological fluids, Anal. Bioanal. Chem. (in press).

[3] M.L. Wang, Y.M. Choong, N.W. Su, M.H. Lee, A rapid method for determination of ethanol in alcoholic beverages using capillary gas chromatography, J. Food Drug Anal. 11(2) (2003), pp. $133-140$

[4] D. Naviglio, R. Ramano, G. Attanasio, Rapid determination of ethanol content in spirits and in beer by high resolution gas chromatography, Industrie delle Bevande 30(172) (2001), pp. 113-115.

[5] S.K. Brill, M.S. Wagner, Alcohol determination in beverages using polar capillary gas chromatography-mass spectroscopy and an acetonitrile internal standard, Concordia College J. Anal. Chem., 3 (2012), pp. 6-12.

[6] S.V. Sumbhate, S. Nayak, D. Goupale, A. Tiwari, R.S. Jadon, Colorimetric method for the estimation of ethanol in alcoholicdrinks, J. Anal. Techn.,1(1) (2012), pp. 1-6.

[7] P. Pinyoua, N. Youngvises, J. Jakmuneea, Flow injection colorimetric method using acidic ceric nitrate as reagent for determination of ethanol, Talanta 84 (2011), pp. 745-751.

[8] P. Tipparat, S. Lapanantnoppakhun, J. Jakmunee, K. Grudpan, Determination of ethanol in liquor by near-infrared spectrophotometry with flow injection, Talanta 53 (2001), pp. 1199-1204.

[9] D.W. Lachenmeier, R. Godelmann, M. Steiner, B. Ansay, J.

Table 4. Potentiostatic measurements of ethanol in hard alcoholic drinks using the catalytic DMFC device.

\begin{tabular}{|c|c|c|c|c|c|c|c|c|c|c|c|}
\hline \multirow[t]{2}{*}{$\begin{array}{l}\text { Sample } \\
\text { type }\end{array}$} & \multirow{2}{*}{$\begin{array}{l}\text { Nominal } \\
\text { value as } \\
\text { (V/V\%) }\end{array}$} & \multirow{2}{*}{$\begin{array}{l}\text { Nominal } \\
\text { value as } \\
\text { (M) } \\
\text { (a) }\end{array}$} & \multicolumn{3}{|c|}{ Found Ethanol (M) } & \multirow{2}{*}{$\begin{array}{l}\text { Mean } \\
\text { (M) } \\
\text { (b) }\end{array}$} & \multirow[t]{2}{*}{ SD (M) } & \multirow[t]{2}{*}{$\begin{array}{l}\Delta \%= \\
{[(b-a) / a] \%}\end{array}$} & \multicolumn{3}{|c|}{$\begin{array}{l}\text { Two sided t-test: } p=95 \% \text {, } \\
\qquad v=3-1=2\end{array}$} \\
\hline & & & Run n. I & Run n. II & Run n. III & & & & $t_{\text {exper. }}$ & $t_{\text {critic }}$ & $\begin{array}{l}\text { Results } \\
\text { of t-test }\end{array}$ \\
\hline $\begin{array}{l}\text { Myrtle } \\
\text { liquor }\end{array}$ & $32 \%$ & 0.0549 & 0.0507 & 0.0574 & 0.0561 & 0.0547 & \pm 0.0036 & -0.30 & -0.080 & 4.303 & N.S. \\
\hline $\begin{array}{l}\text { Berries } \\
\text { grappa }\end{array}$ & $30 \%$ & 0.0515 & 0.0556 & 0.0577 & 0.0512 & 0.0548 & \pm 0.0033 & +6.55 & 1.768 & 4.303 & N.S. \\
\hline Bitters & $27 \%$ & 0.0463 & 0.0433 & 0.0494 & 0.0412 & 0.0446 & \pm 0.0042 & -3.67 & -0.694 & 4.303 & N.S. \\
\hline Rum & $37.5 \%$ & 0.0322 & 0.0319 & 0.03280 & 0.0333 & 0.0326 & \pm 0.0007 & +1.52 & 1.208 & 4.303 & N.S. \\
\hline Whisky & $40 \%$ & 0.0343 & 0.0308 & 0.0300 & 0.0340 & 0.0316 & \pm 0.0021 & -7.92 & -2.247 & 4.303 & N.S. \\
\hline Dry gin & $40 \%$ & 0.0343 & 0.0338 & 0.0359 & 0.0332 & 0.0343 & \pm 0.0014 & +0.02 & 0.009 & 4.303 & N.S. \\
\hline $\begin{array}{l}\text { Old } \\
\text { brandy }\end{array}$ & $38 \%$ & 0.0326 & 0.0384 & 0.0354 & 0.0322 & 0.0353 & \pm 0.0031 & +8.41 & 1.536 & 4.303 & N.S. \\
\hline
\end{tabular}


Weigel, G. Krieg, Rapid and mobile determination of alcoholic strength in wine, beer and spirits using a flow-through infrared sensor, Chem. Cent. J. 4(5) (2010), pp. 1-10.

[10] D.W. Lachenmeier, Rapid quality control of spirit drinks and beer using multivariate data analysis of Fourier transform infrared spectra, Food Chem. 101 (2007), pp. 825-832

[11] Outreach College of Science University of Canterbury Private Bag 4800 Christchurch New Zealand: Determination of ethanol by redox titration with potassium dichromate. www.outreach.canterbury.ac.nz (Accessed March 12, 2014)

[12] R. Angeloni, M. Tomassetti, M. Castrucci, L. Campanella, Ethanol Determination in Alcoholic Beverages Using Two Different Amperometric Enzyme Sensors, Cur. Anal. Chem. 11 (2015) pp. 56-67.
[13] L. Campanella, G. Spuri Capesciotti, T. Gatta, M. Tomassetti, An innovative organic phase enzyme electrode (OPEE) for the determination of ethanol in leadless petrols, Sens. and Actuators B 147 (2010) pp. 78-86.

[14] T.B. Goriushkina, A.P. Soldatkin, S.V. Dzyadevych, Application of amperometric enzyme biosensors for wine and must analysis, Procedia Chemistry 1 (2009), pp. 277-280.

[15] Y. Chen, K. Y. Chen, A.C.C. Tseung, An electrochemical alcohol sensor based on a co-electrodeposited $\mathrm{Pt}$ |WO3 electrode, J. Electroanal. Chem. 471 (1999), pp. 151-155.

[16] C. Calas-Blanchard, M. Cortina-Puig, L. Barthelmebs, T. Noguer, Electrochemical biosensors for the determination of the antioxidant capacity in foods and beverages based on reactive oxygen species, Curr. Anal. Chem. 8(4) (2012), pp. 428-435. 